Roman Bartnicki, Jesus on the Way to Death and Resurrection. A Commentary on the Gospel of Mark 8:27-16:20. I: Mk 8:27-13:37 (original title: Jezus $w$ drodze do śmierci i zmartwychwstania. Komentarz do Ewangelii Marka 8,27-16,20, I, Mk 8,27-13,37) (Warszawa: Instytut Papieża Jana Pawła II 2018). Ss. 606. PLN 50,00. ISBN 978-83-65198-50-1 (paperback)

\title{
MARIUSZ ROSIK
}

Institute of Biblical Studies, Pontifical Faculty of Theology, Wroclaw

e-mail:mrosik@pnet.pl

ORCID: 0000-0002-1943-8649

It might be a bit surprising that, while we are still waiting for the publication of the second volume of the commentary on the Gospel of Mark in the series entitled Nowy Komentarz Biblijny (A New Biblical Commentary; the first volume written by Artur Malina was published in 2013), there appears on the theological market a book whose thematic scope covers precisely the span of the awaited publication. The first volume of the commentary by Artur Malina covers Mk 1:1-8:26, whereas the book of Roman Bartnicki, published in 2018 by Instytut Papieża Jana Pawła II (The Institute of John Paul II) in Warsaw discusses Mk 8:27-13:37 and constitutes the first part of the planned two-volume commentary on Mk 8:27-16:20.

In the title of his work Mark announces that this will be 'the gospel about Jesus Christ, the Son of God' (Mk 1:1) and he consistently pursues the action plan of his work, implicit in this phrase. Two statements referring to the identity of Jesus, one made by Peter ('You are the Christ'; Mk 8:29) and the other one uttered by the centurion ('In truth this man was Son of God'; Mk 15:39) are the climactic moments of his gospel. In this way, the beginning of the gospel (Mk 1:1) and the two confessions delineate the structure of the whole work, which consists in principle of two parts: from the beginning to the confession of Peter near Caesarea Philippi and from this moment to the end of the work. The second part (Mk 8:27-16:20) is the account of Jesus' journey from Galilee to Jerusalem where the most important redemptive events: the passion, death and resurrection of Christ, will take place. And this second part of Mark's work is the object of an insightful commentary by the Rev. Prof. Roman Bartnicki, priest of the Archdiocese of Warsaw, professor at Uniwersytet Kardynała Stefana Wyszyńskiego (The Cardinal Wyszyński University in Warsaw), whose rector he 
was between 1999 and 2005. The first part of the commentary encompasses the content of Mk 8:27-13:37. The very title of the book, Jezus $w$ drodze do śmierci i zmartwychwstania (Jesus on the Way to Death and Resurrection), shows that the author looks at the commented text of Mark's Gospel through the prism of paschal events. And such a viewpoint is by all means accurate since it results directly from the reading of the Evangelist's work.

The book reviewed by excellent biblical scholars (B. Poniży and B. Adamczewski) is preceded by a preface by archbishop Stanisław Gądecki, the President of the Episcopal Conference of Poland. Unfortunately, already in the table of contents, in the very name of KEP (Polish: Konferencja Episkopatu Polski), there are two spelling errors (pp. 5 and 7). The President declares that 'the scholar's conscientiousness, linguistic skills and the clarity of argumentation of previous works guarantee a high academic level of the newly published commentary' (p. 19) and one truly has to agree with this opinion. Apart from the Preface, the List of Abbreviations, Transliteration and Bibliography, the commentary consists of four main parts. In the Preface (pp.21-23) the author states that his intention is to follow the rule formulated by the Second Vatican Council's Dogmatic Constitution on Divine Revelation, Dei verbum: 'the interpreter of Sacred Scripture, in order to see clearly what God wanted to communicate to us, should carefully investigate what meaning the sacred writers really intended, and what God wanted to manifest by means of their words' (12).

The first of the main parts of the book is entitled Introductory Information (pp. 39-104). The author presents here the date and circumstances of the creation of Mark's work, discusses the question of authorship, describes the essential literary features of the text, its structure and initial addressees. These preliminary issues, required in every commentary on biblical books, have been discussed quite extensively by R. Bartnicki. The accuracy of the account of the history of exegesis is impressive. The author refers to the views of earlier researchers on the issues falling within the scope of his interest and then presents the viewpoints of contemporary biblical scholars, which nota bene are very often divergent. The disquisition does not end, however, with discussing the opinions of other scholars, but the author also takes his own stance and provides suitable arguments. What is particularly interesting in the first part of the book is the story of the Roman emperor Vespasian. According to some theologians, Mark's Gospel was meant to be an answer to the propaganda of Vespasian who, like all emperors since Augustus, bore the title of divi filius. It is slightly ironic that this is actually a Roman standing in front of the cross who confesses the faith in the divine sonship of Jesus.

The following three chapters of the book are exegetical and theological in character. They are entitled 'The Journey of the Son of Man from Caesarea 
Philippi to Jerusalem (8:27-10:52)' (pp. 105-364), 'The Ministry of Jesus in Jerusalem (11:1-12:44)' (pp. 365-518) and 'The Eschatological Discourse (13:1-37)' (pp. 519-556), respectively. The first one discusses fifteen pericopes, the second one - eleven, and the third one - four. While analyzing each of the pericopes, the author follows a clearly defined pattern: his own translation of the biblical text, historical and literary issues as well as the exegesis and the kerygma of the reviewed pericope. Textual criticism, which can usually be found directly under the translation of the text proposed by the commentator, has regrettably been omitted, but in the most crucial cases the criticism of textual variants has been included in the notes. The exegesis is mainly based on the historical-critical method, although it is not limited to it. The author of the commentary complements this method with narrative analysis. This is a good decision since the document of the Pontifical Biblical Commission 'The Interpretation of the Bible in the Church' has pointed out the fact that the historical-critical method, widely accepted by biblical scholars until recently, seems to have become insufficient in many ways. The Pontifical Biblical Commission has stated that 'the classic use of the historical-critical method reveals its limitations. It restricts itself to a search for the meaning of the biblical text within the historical circumstances that gave rise to it and is not concerned with other possibilities of meaning which have been revealed at later stages of the biblical revelation and history of the church. Nonetheless, this method has contributed to the production of works of exegesis and of biblical theology which are of great value.' ('The Interpretation of the Bible in the Church' A).

What is extremely useful is the introduction of numerous excursuses into the main body of the commentary. They refer to the following issues: the meaning of the titles 'the Son of God' (ho hyios tou Theou) and 'the Son of Man' (ho hyios tou anthropou), the predictions of passion, death and resurrection in the light of the criteria of authenticity of Jesus' logia, The Secret Gospel of Mark, money and coins, taxes, The Second Temple, or biblical and Judaic traditions concerning the Messiah, son of David. The excursuses considerably broaden the perspective of the interpretation of individual pericopes since they place them in the context of historical, social, political and religious reality of the time of Jesus. Among the topics discussed in the excursuses, one deserves the readers' particular attention and this is the presentation of The Secret Gospel of Mark. It has been mentioned by very few western commentators. In 1958 an American, Morton Smith, discovered in the monastery of Mar Saba a fragment of a letter ascribed to Clement of Alexandria and addressed to one Theodore. The letter referred to The Secret Gospel of Mark which was supposedly written by the Evangelist during his stay in Alexandria and was dedicated only to the chosen ones. The manuscript of the letter comes, judging from the handwriting, from 
the eighteenth or the beginning of the nineteenth century. Smith published it along with an extensive analysis in 1973 in the book entitled Clement of Alexandria and a Secret Gospel of Mark. It concerns essentially the distortions introduced to the canonical Gospel of Mark by a sect of Carpocratians. Who were the Carpocratians? Irenaeus wrote the Carpocratians declared that 'Jesus spoke in a mystery to His disciples and apostles privately, and that they requested and obtained permission to hand down the things thus taught them, to others who should be worthy and believing.' (Adversus haereses $1,25,5$ ) It is good that R. Bartnicki devoted some pages to the presentation of the issue which is relatively unknown to the Polish readers.

Each of the exegetical and theological chapters has been divided into paragraphs whose titles are inspired by the content of the evangelical pericopes. Discussing literary and historical elements of each pericope, R. Bartnicki pays attention to text delimitation, its direct context, structure, narrative analysis, literary genre as well as its historicity, the tradition concerning its creation and final editing. What seems to be of particular value is the presentation of the kerygma of each pericope since the author does not limit himself only to the presentation of his own analysis but he also discusses Wirkungsgeschichte over the course of the history of exegesis. Thus the readers can get to know the different approaches to the interpretation of biblical texts in the Church Fathers, in medieval and postreformation theology, and up to the present time.

The exegesis presented by the author is conscientious and focused on details. This is what makes the publication which discusses only five chapters of Mark's Gospel so extensive. R. Bartnicki analyzes the etymology of particular words, examines their equivalents in biblical languages, invokes the apocryphal tradition of both Old and New Testaments, refers to Qumran texts, to the writings of Josephus and Philo of Alexandria, quotes the Church Fathers and subsequent Christian writers, draws extensively on the achievements of biblical archeology and religious studies and does not avoid resorting to rabbinic tradition. The richness of content makes us hold our breath while reading, all the more that, even though the commentary is written in an academic style, it is at the same time comprehensible to readers who are not professional theologians. What is more, the results of R. Bartnicki's exegetical analyses are in full compliance with the official teaching of the Church which in the light of the commentary appears to be very attractive. The author does not resort to improbable theories bordering on sensation to gain the attention of his readers as many researchers unfortunately do today. He does not have to do it since the style of the book is simple, beautiful and, at the same time, very attractive.

During a meeting with the Pontifical Biblical Commission, Pope John Paul II said, 'The People of God need such exegetes who on the one hand will honestly 
perform their research, but on the other will not stop in the middle of the way but, on the contrary, will continue their efforts until the treasures of light and life contained in Sacred Scripture will be fully presented so that priests and the faithful would have easier access to it and could make more generous use of its fruit.' (April 11, 1991) The commentary by R. Bartnicki undoubtedly implements the above recommendations of the Pope. 
